\title{
Efficacy of the entomopathogenic fungi; Beauveria bassiana and Metarhizium anisopliae against the cowpea weevil, Callosobruchus maculatus F. (Coleoptera: Chrysomelidae: Bruchinae)
}

\author{
Ismail Oguz Ozdemir ${ }^{1 *}$ (D, Celal Tuncer ${ }^{1}$, Ismail Erper ${ }^{1,2}$ and Rahman Kushiyev ${ }^{1}$
}

\begin{abstract}
The efficacy of the two entomopathogenic fungi, Metarhizium anisopliae (TR 106) and Beauveria bassiana (TR 217), was tested against the adults of the cowpea weevil, Callosobruchus maculatus F. (Coleoptera: Chrysomelidae: Bruchinae) in laboratory. Two concentrations of conidial suspensions $\left(1 \times 10^{6}\right.$ and $1 \times 10^{8}$ conidia/ml) of $\mathrm{M}$. anisopliae and B. bassiana isolates were directly applied on four pairs of adult beetles in Petri dishes $(2 \mathrm{ml} / \mathrm{dish})$ and then incubated at two different climatic regimes; $22 \pm 1^{\circ} \mathrm{C}$ and $26 \pm 1{ }^{\circ} \mathrm{C}$ with $70 \pm 5 \% \mathrm{RH}, 16: 8 \mathrm{~h}$ light-to-dark. Lethal time values ( $L T_{50}$ and $L T_{90}$ ) were calculated using probit analysis. As a result, the $L T_{50}$ and $L T_{90}$ values of $M$. anisopliae $\left(1 \times 10^{8}\right.$ conidia/ml) were 4.45 and 5.34 days at $26^{\circ} \mathrm{C}$ and 5.17 and 6.15 days at $22^{\circ} \mathrm{C}$, respectively. $\mathrm{LT}_{50}$ and $L T_{90}$ values of B. bassiana $\left(1 \times 10^{8} \mathrm{Conidia} / \mathrm{ml}\right)$ were 4.07 and 5.11 days at $26^{\circ} \mathrm{C}$ and 4.07 and 5.41 days at $22^{\circ} \mathrm{C}$, respectively. $L T_{50}$ and $L T_{90}$ values of $M$. anisopliae $\left(1 \times 10^{6}\right.$ conidia/ml) were 5.42 and 6.43 days at $26^{\circ} \mathrm{C}$ and 6.08 and 7.54 days at $22^{\circ} \mathrm{C}$, respectively. The $L T_{50}$ and $L T_{90}$ values of $B$. bassiana $\left(1 \times 10^{6}\right.$ conidia/ml) were 5.67 and 7.15 days at $26^{\circ} \mathrm{C}$ and 5.47 and 7.50 days at $22^{\circ} \mathrm{C}$, respectively. Approximately $100 \%$ of mycoses were obtained in all treatments. In general, the effectiveness of these two entomopathogens increased by increasing suspension concentrations and temperature. These results suggest that the two isolates may be very successful in biological control of the C. maculatus and may be alternatives for chemical pest management.
\end{abstract}

Keywords: Callosobruchus maculatus, Cowpea weevil, Entomopathogenic fungi, Virulence, Temperature

\section{Background}

Chickpeas, beans, lentils, peas, broad beans, and cowpea, which are important legumes for human nutrition, are low in fat and high in carbohydrate and have a nutritious feature. In the field and storage stages of legumes, some insect pests usually cause significant damages. Among them, the cowpea weevil, Callosobruchus maculatus F. (Coleoptera: Chrysomelidae: Bruchinae), is found in all regions of Turkey.

The most important damages caused by $C$. maculatus include weight loss, loss in market value (Elhag 2000),

\footnotetext{
* Correspondence: oguz.ozdemir@omu.edu.tr

'Department of Plant Protection, Faculty of Agriculture, Ondokuz Mayis

University, Atakum, Samsun, Turkey

Full list of author information is available at the end of the article
}

decrease in germination ability of seeds (Baier and Webster 1992), and decrease in nutritional value, particularly proteins. The absence of adult diapause of the pest, infestation in the field and storages, and high reproductive potential increase the importance of management against this pest. Nonetheless, it has been reported that $1-2 \%$ field infestation may raise to $80 \%$ after 6 months of storage period (Youdeowei 1989).

Numerous synthetic insecticides and fumigants are used against stored product pests (Arthur 1996). However, potential risks posed by synthetic insecticides for mammals, concerns of consumers on pesticide residues in processed legume products, insecticidal-resistant insect populations, ecological implications, increased application costs, and the necessity precautionary measures 
when using these chemicals have urged the researchers to develop alternative control strategies against stored product pests (Mahdi and Rahman 2008).

Entomopathogenic fungi (EPF) are effective biological control agents against various pests (Roy et al. 2006). Recently, there is an increasing interest in the use of EPF for the development of biological control strategies against stored product pests. Among EPF, the biological control potential of Beauveria bassiana (Bals.) Vuill., Metarhizium anisopliae (Metch) Sorok, and Isaria fumosorosea Wize has been studied against various pests, in particular, C. maculatus (Vilas Boas et al. 1996; Rice and Cogburn 1999; Padin et al. 2002; Batta 2005; Cherry et al. 2005, 2007; Sewify et al. 2014; Athanassiou et al. 2017; Iqbal et al. 2018).

Temperature is among the most important factors limiting the efficacy of EPF (Fernandes et al. 2008). Generally, optimum temperature for germination, development, sporulation, and virulence of EPF ranges from 20 to $30{ }^{\circ} \mathrm{C}$ (Tefera and Pringle 2003; Dimbi et al. 2004; Kiewnick 2006). Therefore, different temperatures used in different studies have led to varying results. Lawrence and Khan (2002) reported that two different B. bassiana isolates were applied to cowpea seed beetle at different temperatures $\left(20,25\right.$, and $\left.30^{\circ} \mathrm{C}\right)$ and the lowest $\mathrm{LC}_{50}$ and $\mathrm{LT}_{50}$ values were determined at $30^{\circ} \mathrm{C}$.

This study was conducted to assess the efficacy of two conidial concentrations of $M$. anisopliae (TR-106) and B. bassiana (TR-217) against C. maculatus adults at two different temperatures under laboratory conditions.

\section{Materials and methods} Insect culture

Initially, C. maculatus was obtained from chickpea seeds stored in the Department of Field Crops, Faculty of Agriculture, Ondokuz Mayıs University, Samsun, Turkey. Chickpeas were kept at $-20^{\circ} \mathrm{C}$ for 2 weeks to eliminate all infesting pests before starting the experiments (Cherry et al. 2005). The obtained C. maculatus adults were placed in glass jars $(500 \mathrm{ml})$ having $200 \mathrm{~g}$ of sterilized chickpea seeds. The glass jars were placed under conditions of $26^{\circ} \mathrm{C}, 70 \%$ relative humidity, and 16:8 light-to-dark period for obtaining eggs. The culture was sieved daily to obtain male and female adults.

\section{Preparation of entomopathogenic fungi}

M. anisopliae TR-106 and B. bassiana TR-217 isolates used in this study were isolated from adults of Xylosandrus germanus Blandford (Coleoptera: Curculionidae: Scolytinae), which is one of the important hazelnut pests (Tuncer et al. 2018). The isolates were plated on potato dextrose agar (PDA; Merck Ltd., Darmstadt, Germany) in 9-cm-diameter Petri dishes, incubated at $25^{\circ} \mathrm{C}$ with a complete dark for 10-12 days. At the end of the growth period, $10 \mathrm{ml}$ sterile distilled water containing $0.02 \%$ Tween 20 was added to each dish. The spore suspensions were then filtered through two layers of cheesecloth to remove the micelle structures and were homogenized by vertexing for $3 \mathrm{~min}$. The resulting spore suspensions were adjusted to concentrations of $1 \times 10^{6}$ and $1 \times 10^{8}$ conidia/ml, using Neubauer hemocytometer, under Olympus CX31 light microscope (Olympus America Inc., Lake Success, NY) (Kushiyev et al. 2018).

\section{Conidial germination assessment}

The viability of conidia of the EPF isolates was determined. A conidial suspension was adjusted to $1 \times 10^{4}$ conidia/ml and $0.1 \mathrm{ml}$ was sprayed onto Petri dishes $(9 \mathrm{~cm}$ diameter, containing PDA), and the dishes were incubated at $25^{\circ} \mathrm{C}$. After $24 \mathrm{~h}$ of incubation, percentage of germinated conidia was determined by examining of 200 conidia from each of three replicate dishes, using Olympus CX31 compound microscope $(-400)$. Conidia were regarded as germinated when they produced a germ tube at least half of the conidial length (Erper et al. 2016).

\section{Application of EPF to C. maculatus adults}

Two layers of sterile filter papers were placed in plastic Petri dishes and moistened with $1 \mathrm{ml}$ of sterile distilled

Table 1 The $\mathrm{LT}_{50}$ and $\mathrm{LT}_{90}$ values of Metarhizium anisopliae against Callosobruchus maculatus at 2 different concentrations and temperatures

\begin{tabular}{|c|c|c|c|c|}
\hline \multirow[t]{2}{*}{ Variables } & \multicolumn{2}{|l|}{$22^{\circ} \mathrm{C}$} & \multicolumn{2}{|l|}{$26^{\circ} \mathrm{C}$} \\
\hline & $1 \times 10^{6}$ & $1 \times 10^{8}$ & $1 \times 10^{6}$ & $1 \times 10^{8}$ \\
\hline $\mathrm{LT}_{50}$ (95\% fid. limit) & 6.64 (6.08-7.38)a & $5.46(5.17-5.74) b$ & $5.42(4.72-6.01) b c$ & $4.44(3.89-5.01) \mathrm{c}$ \\
\hline $\mathrm{LT}_{90}(95 \%$ fid limit $)$ & 8.43 (7.54-11.06)a & $6.52(6.15-7.15) b$ & $6.43(5.84-8.31) a b$ & $5.34(4.79-7.27) b$ \\
\hline Slope \pm SE & $12.37 \pm 1.98$ & $16.54 \pm 2.55$ & $17.31 \pm 2.71$ & $16.08 \pm 2.71$ \\
\hline Regression equation & $y=-10.18+12.37$ & $y=-12.19+16.54$ & $y=-12.72+17.31$ & $y=-10.42+16.08$ \\
\hline$x^{2}$ & 46.1 & 15.54 & 75.92 & 46.14 \\
\hline$d f$ & 22 & 22 & 22 & 16 \\
\hline Heterogeneity & 2.09 & 0.7 & 3.45 & 2.88 \\
\hline
\end{tabular}

*Means followed by same lowercase letter within a row do not differ significantly at $p \leq 0.05$ 
Table 2 The $\mathrm{LT}_{50}$ and $\mathrm{LT}_{90}$ values of Baeuveria bassiana against Callebruchus maculatus at two different concentrations and temperatures

\begin{tabular}{|c|c|c|c|c|}
\hline \multirow[t]{2}{*}{ Variables } & \multicolumn{2}{|l|}{$22^{\circ} \mathrm{C}$} & \multicolumn{2}{|l|}{$26^{\circ} \mathrm{C}$} \\
\hline & $\overline{1 \times 10^{6}}$ & $1 \times 10^{8}$ & $\overline{1 \times 10^{6}}$ & $1 \times 10^{8}$ \\
\hline $\mathrm{LT}_{50}$ (95\% fid. limit) & $5.87(5.47-6.32) a$ & $4.61(4.07-5.15) b$ & $5.67(5.35-5.99) a$ & $4.07(3.71-4.39) b$ \\
\hline $\mathrm{LT}_{90}$ (95\% fid.limit) & 8.28 (7.5-9.7)a & $6.1(5.41-7.71) a b$ & 7.15 (6.69-7.93)a & $5.11(4.7-5.9) b$ \\
\hline Slope \pm SE & $8.59 \pm 1.28$ & $10.49 \pm 1.4$ & $12.77 \pm 1.89$ & $12.97 \pm 2.11$ \\
\hline Regression equation & $y=-6.6+8.59$ & $y=-6.96+10.49$ & $y=-9.63-9.63$ & $y=-7.91+12.97$ \\
\hline$x^{2}$ & 11.77 & 52.63 & 16.2 & 22.34 \\
\hline$d f$ & 22 & 22 & 22 & 18 \\
\hline Heterogeneity & 0.53 & 2.39 & 0.73 & 1.24 \\
\hline
\end{tabular}

*Means followed by same lowercase letter within a row do not differ significantly at $p \leq 0.05$

water. Afterwards, four pairs of C. maculatus adults were released into the dishes containing $15 \mathrm{~g}$ chickpeas and sprayed with $2 \mathrm{ml}$ of spore suspensions $\left(1 \times 10^{6}\right.$ or $1 \times 10^{8}$ conidia $/ \mathrm{ml})$. The control insects were sprayed by sterile distilled water containing $2 \mathrm{ml}$ of $0.02 \%$ Tween 20 . All Petri dishes were sealed with a parafilm and incubated for 10 days at two different temperatures $\left(22\right.$ and $\left.26^{\circ} \mathrm{C}\right), 70 \% \mathrm{RH}$, and 16:8 light-to-dark. The mortality rate was recorded daily for 8 days. The experiment was repeated daily at the same time with the same number ( $n=24$ adults/day/isolate/concentration/temperature) and different adults to keep the mortality rates of every day independent from each other (Robertson et al. 2007). The dead C. maculatus individuals were surface sterilized by $1 \%$ sodium hypochlorite and $70 \%$ ethyl alcohol. Then, these insects were washed with sterile distilled water, placed in Petri dishes having filter paper, and kept at $25^{\circ} \mathrm{C}$ and $90 \% \mathrm{RH}$ for 10 days. The dead adults were examined under a microscope to determine whether the cause of death was fungus, and mycosis rates were determined.

\section{Statistical analyses}

The daily mortality rates at different doses were corrected according to the Abbott formula when the mortality rate in the control exceeded 5\% (Abbott 1925). The $\mathrm{LT}_{50}$ and $\mathrm{LT}_{90}$ values were determined by probit analysis, using the log-probit method (POLO-PLUS ver.2.0). The slopes of the regression lines were compared with each other using standard errors, and the $\mathrm{LT}_{50}$ and $\mathrm{LT}_{90}$ values of the isolates were compared using confidence intervals (95\%).

\section{Results and discussion}

Conidia viability of the two isolates (TR-106 and TR217) was assessed before bioassays, and approximately (100\%) germination was obtained. The $\mathrm{LT}_{50}$ and $\mathrm{LT}_{90}$

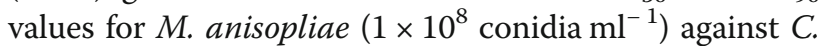
maculatus were 4.44 and 5.34 days, respectively, at $26^{\circ} \mathrm{C}$, whereas at $22^{\circ} \mathrm{C}$, they were 5.46 and 6.52 days, respectively (Table 1 ). The respective $\mathrm{LT}_{50}$ and $\mathrm{LT}_{90}$ for $B$.

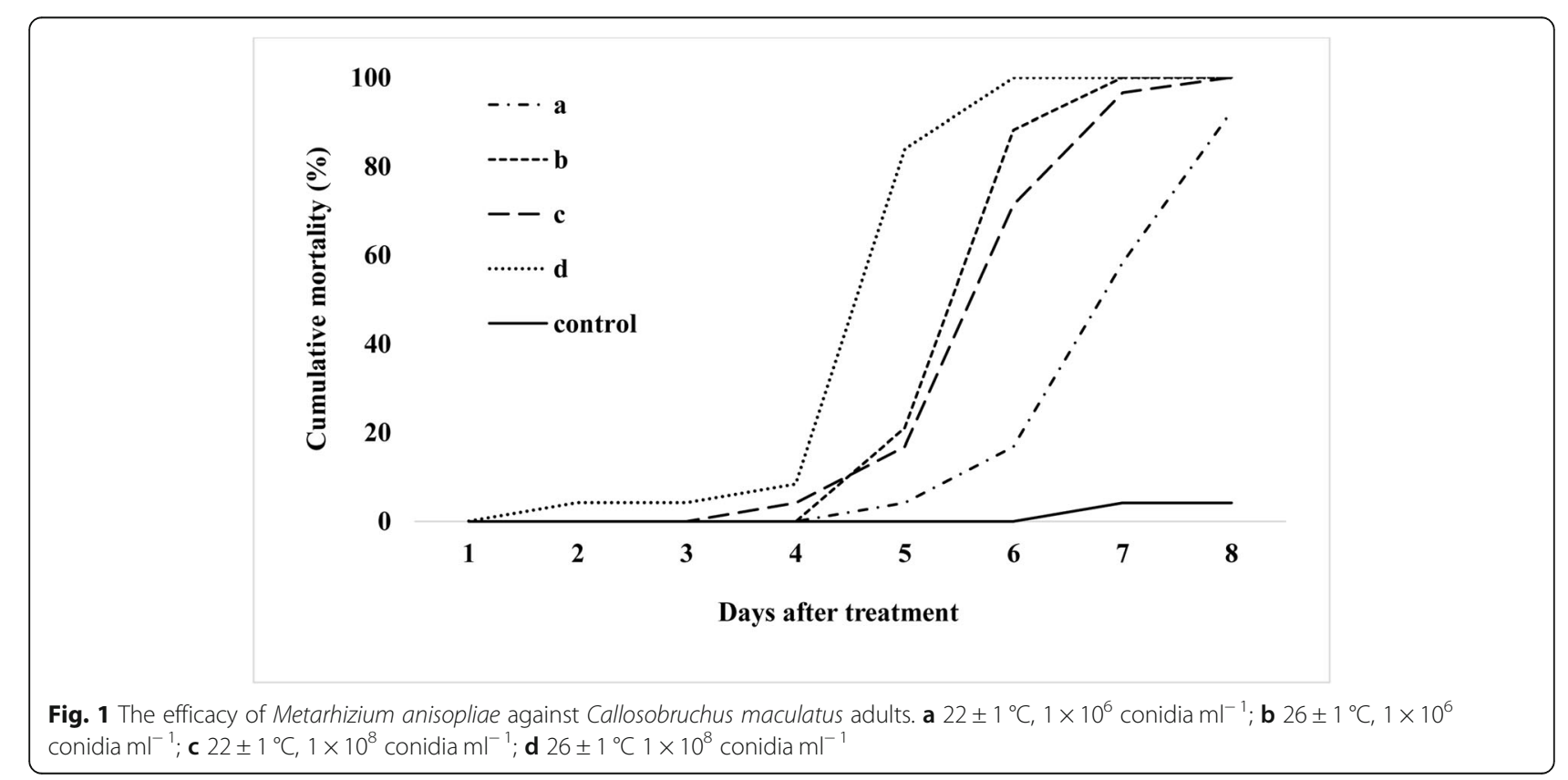




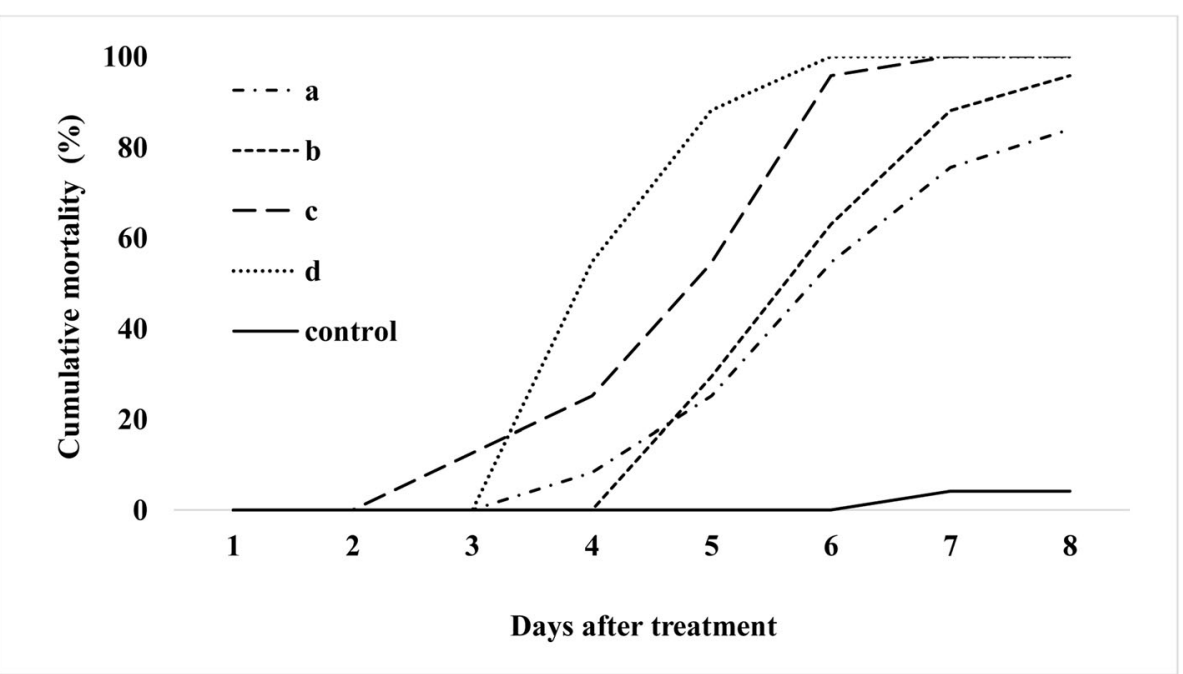

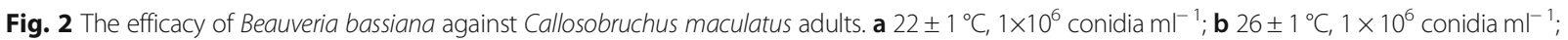

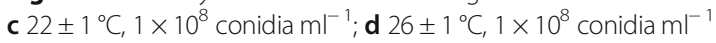

bassiana were 4.07 and 5.11 days at $26^{\circ} \mathrm{C}$ and 4.61 and 6.10 days at $22^{\circ} \mathrm{C}$.

The $\mathrm{LT}_{50}$ and $\mathrm{LT}_{90}$ values for $M$. anisopliae $\left(1 \times 10^{6}\right.$ conidia $\mathrm{ml}^{-1}$ ) were 5.42 and 6.43 days, respectively, at $26^{\circ} \mathrm{C}$, whereas at $22^{\circ} \mathrm{C}$, they were 6.64 and 8.43 days, respectively (Table 1 ). The respective values for $B$. bassiana were 5.67 and 7.15 days at $26^{\circ} \mathrm{C}$ and 5.87 and 8.28 days at $22^{\circ} \mathrm{C}$ (Table 2). In addition, approximately $100 \%$ mycosis rate was obtained in all treatments.

It was observed that the two tested concentrations of the two isolates at both temperatures started to cause mortality in 4 days after application and mortality increased by the time (Figs. 1 and 2). The $1 \times 10^{8}$ concentration of the two species caused $100 \%$ mortality, 8 days after application. Similarly, the $1 \times 10^{6}$ concentration of M. anisopliae caused $100 \%$ mortality, 8 days after application at $26^{\circ} \mathrm{C}$. Nonetheless, 84 to $96 \%$ mortality rate was noted in the other treatments (Figs. 1 and 2).

B. bassiana and $M$. anisopliae have been found to be the most effective EPF against various pests (Vilas Boas et al. 1996; Lawrence and Khan 2002). Cherry et al. (2005) reported that $B$ bassiana (0306 isolate) obtained from the insect belonging to the Scolytidae family did not have high virulence against $C$. maculatus.

Temperature is one of the leading abiotic factors affecting the development of fungi, which in turn significantly affects the virulence of EPF against harmful insects. For instance, Ak (2019) reported that B. bassiana caused the highest mortality (93.66\%) at $25^{\circ} \mathrm{C}$ and the lowest (40.74\%) against Sitophilus oryzae (Coleoptera: Curculionidae) at $20^{\circ} \mathrm{C}$. Similarly, Vassilakos et al. (2006) reported that B. bassiana was more effective against $S$. oryzae and Rhyzopertha dominica (Coleoptera: Bostrichidae) at $26^{\circ} \mathrm{C}$ than at $30^{\circ} \mathrm{C}$. Similar results were obtained by Athanassiou and Steenberg (2007).
Comparing the $\mathrm{LT}_{50}$ values obtained in the present study to the others, Vilas Boas et al. (1996) reported that $M$. anisopliae and B. bassiana at a concentration of $1 \times$ $10^{8}$ conidia/ml against the adults of $C$. maculatus ranged between 3.46 for B. bassiana and 6.78 for M. anisopliae. Similarly, Cherry et al. (2005) reported that the $\mathrm{LT}_{50}$ values for $C$. maculatus by $M$. anisopliae 0351 isolate and $B$. bassiana 0362 isolate at $1 \times 10^{8}$ spores $/ \mathrm{ml}$ were found to be 3.27 and 3.11 days, respectively.

\section{Conclusion}

The two evaluated EPF in this study (M. anisopliae TR106 and B. bassiana TR-217 isolates) showed a virulence against C. maculatus (causing up to $100 \%$ mortality). Thus, they seem to be promising biocontrol agents against this pest. However, further studies are needed to determine their effectiveness under storage conditions.

Acknowledgements

Rahman Kushiyev is thankful to the Scientific and Technological Council of Turkey (TUBITAK) for providing fellowship.

\section{Authors' contributions}

IOO, CT, IE, and RK designed the study, supervised the work, and wrote the manuscript with input from all the authors. IOO, CT, IE, and RK carried out the experiments. CT analyzed the data. All authors read and approved the final manuscript.

\section{Funding}

No funding.

Availability of data and materials

The datasets used and/or analyzed during the current study are available from the corresponding author on reasonable request.

Ethics approval and consent to participate Not applicable. 


\section{Consent for publication}

Not applicable.

\section{Competing interests}

The authors declare that they have no competing interests.

\section{Author details}

${ }^{1}$ Department of Plant Protection, Faculty of Agriculture, Ondokuz Mayis University, Atakum, Samsun, Turkey. ${ }^{2}$ Department of Plant Protection, Faculty of Agriculture, Kyrgyz Turkish Manas University, 720044 Bishkek, Kyrgyzstan.

Received: 3 December 2019 Accepted: 10 February 2020

Published online: 06 March 2020

\section{References}

Abbott WS (1925) A method of computing the effectiveness of an insecticide. J Econ Entomol 18(2):265-267

Ak K (2019) Efficacy of entomopathogenic fungi against the stored-grain pests, Sitophilus granarius L. and S. oryzae L. (Coleoptera: Curculionidae). Egypt J Biol. Pest Control 29(1):12

Arthur FH (1996) Grain protectants: current status and prospects for the future. J Stored Prod Res 32:293-302

Athanassiou CG, Kavallieratos NG, Rumbos Cl, Kontodimas DC (2017) Influence of temperature and relative humidity on the insecticidal efficacy of Metarhizium anisopliae against larvae of Ephestia kuehniella (Lepidoptera: Pyralidae) on wheat. J Insect Sci 17(1)

Athanassiou CG, Steenberg T (2007) Insecticidal effect of Beauveria bassiana (Balsamo) Vuillemin (Ascomycota: Hypocreales) in combination with three diatomaceous earth formulations against Sitophilus granarius (L.) (Coleoptera: Curculionidae). Biol Control 40:411-416

Baier AH, Webster BD (1992). Control of Acanthoscelides obtectus Say (Coleoptera: Bruchidae) in Phaseolus vulgaris L. seed stored on small farms-I. Evaluation of damage. J Stored Prod Res 28(4):289-293

Batta YA (2005) Control of the lesser grain borer (Rhyzopertha dominica (F.), Coleoptera: Bostrichidae) by treatments with residual formulations of Metarhizium anisopliae (Metschnikoff) Sorokin (Deuteromycotina: Hyphomycetes). J Stored Prod Res 41:221-229

Cherry AJ, Abalo P, Hell K (2005) A laboratory assessment of the potential of different strains of the entomopathogenic fungi Beauveria bassiana (Balsamo) Vuillemin and Metarhizium anisopliae (Metschnikoff) to control Callosobruchus maculatus (F.) (Coleoptera: Bruchidae) in stored cowpea. J Stored Prod Res 41(3):295-309

Cherry AJ, Abalo P, Hell K, Korie S (2007) Farm-scale trials to compare the entomopathogenic fungus Beauveria bassiana with pirimiphos methyl + deltamethrin and essential oil of lemon grass for protection of stored cowpea against Callosobruchus maculatus (Coleoptera: Bruchidae). Ann Appl Biol 151(1):1-10

Dimbi S, Maniania NK, Lux SA, Mueke JM (2004) Effect of constant temperatures on germination, radial growth and virulence of Metarhizium anisopliae to three species of African tephritid fruit flies. Biocontrol 49:83-94

Elhag EA (2000) Deterrent effects of some botanical products on oviposition of the cowpea bruchid Callosobruchus maculatus (F.) (Coleoptera: Bruchidae). Int J Pest Manage 46(2):109-113

Erper I, Saruhan I, Akça I, Aksoy HM, Tuncer C (2016) Evaluation of some entomopathogenic fungi for controlling the green shield bug, Palomena prasina L. (Heteroptera: Pentatomidae). Egypt J Biological Pest Control 26(3): 573-578

Fernandes ÉK, Rangel DE, Moraes ÁM, Bittencourt VR, Roberts DW (2008) Cold activity of Beauveria and Metarhizium, and thermo-tolerance of Beauveria. J Invertebrate Pathol 98(1):69-78

lqbal M, Shaheen FA, Naz F, Raja MU, Fiaz M, Nadeem M (2018) Management of Callosobruchus chinensis I.(Coleoptera: Bruchidae) in stored chickpea grains by using entomopathogenic fungi. Pakistan J Agri Res 31(4)

Kiewnick S (2006) Effect of temperature on growth, germination, germ-tube extension and survival of Paecilomyces lilacinus strain 251. Biocontrol SC Technol 16:535-546

Kushiyev R, Tuncer C, Erper I, Ozdemir IO, Saruhan I (2018) Efficacy of native entomopathogenic fungus, Isaria fumosorosea, against bark and ambrosia beetles, Anisandrus dispar Fabricius and Xylosandrus germanus Blandford (Coleoptera: Curculionidae: Scolytinae). Egypt J Biological Pest Control 28(1):55
Lawrence AA, Khan A (2002) Comparison of the pathogenicity of the entomopathogenic fungi, Beauveria bassiana, Metarhizium anisopliae, and Paecilomyces fumosoroseus to Callosobruchus maculatus. Int Pest Contr 44(3): 125-127

Mahdi SH, Rahman MK (2008) Insecticidal effect of some spices on Callosobruchus maculatus (Fabricius) in black gram seeds. University J Zoology 27:47-50

Padin SB, Dal-Bello G, Fabrizio M (2002) Grain loss caused by Tribolium castaneum, Sitophilus oryzae and Acanthoscelides obtectus in stored wheat and beans treated with Beauveria bassiana. J Stored Prod Res 38:69-74

Rice WC, Cogburn RR (1999) Activity of the entomopathogenic fungus Beauveria bassiana against three coleopteran pests of stored grain. J Eco Entomol 92: 691-694

Robertson JL, Russell RM, Preisler HK, Savin E (2007) Bioassays with arthropods, 2nd edn. CRC Press, Boca Raton, p 199

Roy HE, Steinkraus DC, Eilenberg J, Hajek AE, Pell JK (2006) Bizarre interactions and endgames: entomopathogenic fungi and their arthropod hosts. Annu Rev Entomol 51:331-357

Sewify GH, El Shabrawy HA, Eweis ME, Naroz MH (2014) Efficacy of entomopathogenic fungi, Beauveria bassiana and Metarhizium anisopliae for controlling certain stored product insects. Egypt J Biol Pest Control 24(1):191

Tefera T, Pringle K (2003) Germination, radial growth, and sporulation of Beauveria bassiana to Chilo partellus (Lepidoptera: Pyralidae) at different temperatures. Biocontrol Sci Technol 13:699-704

Tuncer C, Kushiyev R, Erper I (2018) Determination of fungal flora on Anisandrus dispar Fabricius and Xylosandrus germanus Blandford (Coleoptera: Curculionidae: Scolytinae). Acta Horticul 1226

Vassilakos TN, Athanassiou CG, Kavallieratos NG, Vayias BJ (2006) Infuence of temperature on the insecticidal effect of Beauveria bassiana in combination with diatomaceous earth against Rhyzopertha dominica and Sitophilus oryzae on stored wheat. Biol Control 38:270-281

Vilas Boas AM, Oliveira JV, Campos AL, Andrade RM, Silva RLX (1996) Pathogenicity of wild strain and mutants of Metarhizium anisopliae and Beauveria bassiana to Callosobruchus maculatus (Coleoptera: Bruchidae). Braz Arch Biol Technol 39:99-104

Youdeowei A (1989) Major arthropod pests of food and industrial crops of Africa and their economic importance. In The Search for Sustainable Solutions to Crop Pest Problems in Africa, Cotonou (Benin), 5-9 Dec, IITA

\section{Publisher's Note}

Springer Nature remains neutral with regard to jurisdictional claims in published maps and institutional affiliations.

\section{Submit your manuscript to a SpringerOpen ${ }^{\circ}$ journal and benefit from:}

- Convenient online submission

- Rigorous peer review

- Open access: articles freely available online

High visibility within the field

- Retaining the copyright to your article

Submit your next manuscript at $\boldsymbol{\nabla}$ springeropen.com 